\title{
Proceeding
}

Supplementary Issue: Autumn Conferences of Sports Science. Costa Blanca Sports Science Events, 18-19 December 2020. Alicante, Spain.

\section{Sport as a tool of soft power in modern international relations}

\author{
BULAT GUMARBAEVICH AKHMETKARIMOV $\triangle$, RITA RINATOVNA AMINOVA \\ Kazan Federal University, Russian Federation
}

\begin{abstract}
What is the relationship between international relations and sports? Research on sports diplomacy suggests that sports has historically played an important role in bringing nations and cultures together. However, few studies have attempted to suggest an adequate theoretical framework for the analysis of the relationship. This study aims to fill this research lacuna. Authors advance the hypothesis that many countries in contemporary international relations increasingly rely on sports as a soft power tool. Furthermore, international organizations such as FIFA and FISU have lately evolved into important actors of global affairs. This article discusses an increasing role of sports in international relations. In doing so, authors examine the correlation between the number and scale of international sports events hosted by countries and respective changes in their foreign policy. Authors support theoretical conclusions by original data collected in Russia. Preliminary findings suggest that sports can play an effective role in promotion of peace, security, and sustainable development. Suggested framework largely explains the efforts of nation-states to host international sports competitions and offers predictive insights on the role of major sports competitions in international relations in the future.
\end{abstract}

Keywords: Sports: International relations; FIFA; FISU; Soft power; Olympic Games.

Cite this article as:

Akhmetkarimov, B.G., \& Aminova, R.R. (2021). Sport as a tool of soft power in modern international relations. Journal of Human Sport and Exercise, 16(2proc), S421-S426. doi:https://doi.org/10.14198/jhse.2021.16.Proc2.27

Corresponding author. Kazan Federal University, Russian Federation.

E-mail: $\underline{b}$ search57@yahoo.com

Abstract submitted to: Autumn Conferences of Sports Science. Costa Blanca Sports Science Events, 18-19 December 2020. Alicante, Spain.

JOURNAL OF HUMAN SPORT \& EXERCISE ISSN 1988-5202

(C) Faculty of Education. University of Alicante

doi:10.14198/jhse.2021.16.Proc2.27 


\section{INTRODUCTION}

\section{Theoretical framework and historical background}

The concept of "sports diplomacy" has recently become popular in scholarly exchange. Nevertheless, the historical origins of the concept go back as far as Ancient Greece. For the duration of Olympic Games echeria (sacred truce) was announced throughout Greece. This means that during the Games all active military operations had to be suspended. In modern use many researchers rely on the Australian professor Stuart Murray's definition of "sports diplomacy" (Murray, 2011; Beato \& Silveira, 2018). According to him, the term sports diplomacy means a conscious, strategic, and regular use of sports, athletes, and sports events by the state and non-state actors to engage, inform and create a favourable public image of itself, with the ultimate goal to shape perceptions «in a way that is (more) conducive to the sending group's desired goals».

\section{METHODS}

Research methods are presented via historical and contemporary documentary research, investigative journalism, analysis of the international organizations' sources and participant-observer research. Relevant theoretical literature has been reviewed, through which the components (items) connected with the sports diplomacy have been taken into account.

\section{RESULTS}

We can point out following factors that contribute to the spread and growth of the role of sports diplomacy in the modern world. Primarily these are paradigm shifts in international relations - if in the past diplomacy meant to a greater extent only the interaction of states with each other, now the circle of international actors has expanded significantly (llikova \& Glushkova, 2019). Because of the dramatic increase in the number of sports organizations and participants in sports events international relations have become more complex. Secondly, sports and diplomacy have identified common tasks and values such as promotion and maintaining peace, intercultural exchanges and etc. Organized sports as an institute of civil society are perceived as humanitarian effort to solve acute problems, both in domestic and foreign policy.

An American political scientist, diplomat, civil servant, and Professor Condoleezza Rice once noted: "Sports and athletes have the opportunity to bring people together with different religions, races and areas. Through sports around the world, we send messages of international comprehension, cultural tolerance, and mutual respect' (Walters, 2007; Tonekaboni \& Abianeh, 2020). Sports enhances international exchange, allows fans of sporting events to overcome political differences and establish dialogue between countries, often in an exceedingly difficult and sometimes tough political environment. At the conference organized by the IOC in Buenos Aires before the Winter Olympic Games in PyeongChang, the former UN Secretary General also spoke about the indispensable role of sport in peacekeeping processes: "I have never seen such excitement and hope with all people around the world in this life that peace and security will soon come, and even a possible reunion on the Korean peninsula. At that moment, we had witnessed the power of sports. Both the South and the North have really tried to come to terms, at least for 3-4 decades, but over the past months we saw the moment of truth, which, we hope, will come soon, we will be able to advance much better, understanding and even reconciling Korean peninsula" (Ban Ki-moon centre for Global citizens, 2020).

Sports, thanks to its ability to bring together a large number of athletes and fans, the representatives of governments, business, media, and wider society has become a unique way to attract people's attention to the global issues. A significant role is devoted to the International Olympic Committee (IOC) - an authoritative 
and specialized structure in the global sports community. In its humanitarian work in the fields of education, culture, and sustainable development, the IOC actively cooperates with major world powers and authoritative intergovernmental organizations of the United Nations system: UNESCO, WHO, UNEP.

The independence of the International Olympic Committee, the apolitical stance of regional and national Olympic sports organizations is legally enshrined in their founding charters. Yet, at times, the clear desire of one or another party to use sports organizations in their own often political interests is well known. Some of the well-known examples are the historical precedent of the political propaganda and racial segregation during the Olympic Games of 1936, the boycott by many Western countries of the Moscow Olympics in 1980 and the response boycott from the countries of the socialist camp of the Olympic Games in 1984 in Los Angeles. Similarly, Pakistani, and Indian sports teams had to meet on neutral fields or completely stop meeting due to the terrorist attack in Mumbai in 2009 (Neilson company, 2020).

The increasing intensification of international processes, including the constant growth of transnational companies and their penetration into the sphere of international sports, shows that sports diplomacy is progressing more and more in the international arena. At the same time attention to sports is also increasing at the national levels: in many countries new sports facilities are being built, the sphere of culture and physical sports is being supported, new sports oriented academic programs are opened at universities, etc. In Russia, for example, in 2006 the "Olympic Diploma 2007" program was launched at the Moscow State Institute of International Relations (MGIMO). It is aimed to train managers in the field of international sports diplomacy. In 2009, the Russian International Olympic University was created in Russia, where Russian and foreign students are offered grants to study the sports components of diplomacy.

\section{DISCUSSION}

It is widely accepted that sports diplomacy is primarily aimed at strengthening peace, friendship, cooperation, and mutual understanding between peoples. Yet, sports diplomacy has its own legal basis, goals, and objectives. One of the fundamental international legal documents in this area is the Olympic Charter, which sets out the basic rules, principles and official provisions adopted by the IOC. Other examples include the International Charter of Physical Education and Sports, the European Sports Charter, charters of various international sports organizations and etc (Beacom, 2000). All of them are targeted at ensuring sustainable development, promoting collaboration in the sports field, and promoting peaceful initiatives. The United Nations also gives a special place to sports and sports diplomacy. The UN established the Office on Sport for Development and Peace in May 2004. This office is aimed to support and develop sport, its promotion, as well as to develop and popularize sports diplomacy. Earlier in 1987 the Intergovernmental Committee for Physical Education and Sport (CIGEPS) was established, with a permanent advisory board.

In general, the UN perceives sports diplomacy as one of the successful tools for maintaining peace and international security, promoting healthy lifestyle. In addition, sports diplomacy is seen by the UN not only as a way to unite the world community, but also as an attempt to restore peace. For example, in March 2019, a series of seminars on "Youth and sports for social unity» took place in Syria. The event was held jointly by UNESCO and the Ministry of Education of Syria (Muhametzyanov, 2014). Sports diplomacy, as a special tool, can be used in different cases. For example, not only for providing humanitarian assistance, but also for developing large-scale cooperation projects both at local, regional, and even global levels ("Sport for Peace and Development" - projects supported by UNESCO) (UNESCO, 2020). 
Sports can play an important role in building and strengthening regional cooperation and alliances. For example, Central Asian sports teams regularly meet with Russian athletes and some of them are successfully integrated into regional leagues. In part, this contributes to Russia's efforts to provide security in Central Asia (Beloglazov, 2015). More broadly, such exchanges allow to make stronger connections between the East and the West (Muhametzyanov, 2014). This is especially relevant given wars and military conflicts in the XXI century (Penkovtsev \& Shibanova, 2015; llikova \& Venidiktova, 2019).

The international sports organizations' role at the international level is also rapidly changing. In the modern world, they have become a significant institution in the development of international relations. International sports organizations, such as the IOC or FISU, have taken a position not only as a driving force in the development of the sports sector, but also acquired new functions that were previously not associated with it. Thus, the activity of FISU is practically the subject of multilateral diplomacy and includes an extensive set of measures affecting various areas. This organization implements activities in such areas as promoting a healthy lifestyle, developing a sports culture and sports education among young people from different countries. This also contributes to enhancing ties between cities where international competitions such as the Universiade are held. Cities and local governments exchange with experience in preparing for the events. A vivid example of such an activity of FISU is the FISU Volunteer Leaders Academy - an international educational forum designed to unite participants in the volunteer movement, representatives of the organizing committees of the Universiades and various world championships. The last forum was held in Kazan (2019, September) where foreign participants got acquainted not only with unique Russian culture, but also discovered the peculiarities of the Tatar people traditions (ANO Directorate for sports and social projects, 2019).

Taken into account all these examples, we can conclude that in the modern world, international sports organizations can be considered as actors not only in sports diplomacy, but also in international relations in general.

Given the comprehensive integration of sports diplomacy in social processes, it also protects and gives paramount importance to human rights and equality of people, helps to prevent conflicts, and also indirectly supports economic development. In practice, these goals are achieved in various ways. For example, famous athletes often try on the role of goodwill ambassadors: David Beckham, Lionel Messi, Iker Casillas, and others served in this capacity. Most of them not only promote the development of sports and healthy lifestyles, but also help to draw attention to any problem. requiring immediate action. Another such example is the cooperation of the UN with other sports organizations, for example, UNESCO and FIFA, which jointly developed the Kazan Action Plan 2017 (UNESCO Media Services, 2020).

For the development of sports diplomacy, the United Nations has adopted specific documents. Among the UN resolutions on sports diplomacy, one can single out such "Sport as a means to promote education, health, development and peace" (October 31, 2014), which enshrines the provisions of the Olympic Charter that sports competitions should be held in a spirit of peace, promote development of mutual understanding, friendship, tolerance and equality between peoples; Resolution adopted by the UN General Assembly "Observance of the Olympic Truce", the main purpose of which is the prevention of any armed conflicts during the Olympic Games; UN General Assembly Resolutions on d "Building a peaceful and better world through sport and the Olympic ideal"; Resolution "International Year of Sports and Olympic Ideals" of 1993; The 1995 United Nations Resolution on Olympic Ideals, affecting cooperation on anti-doping programs and environmental issues (Cutlip et al., 1994). 


\section{CONCLUSION}

Sports combines elements of politics, business, and mass media. On the one hand, at present it seems very difficult to imagine the Olympics without television broadcasts, the speeches of state leaders at the opening ceremonies of sporting events, and special advertising of leading sports brands. Without such support it would be difficult to promote large scale events. On the other hand, despite the principle of "sports away from politics", the history of the Olympic movement for over a century shows that it was unable to maintain political neutrality in the context of political challenges and the transformation of the world political system. As researcher D. Kanin notes, "it's pointless to call for separation of sports from politics, because competitions such as the Olympics are inseparable from world politics".

Although the Olympic Games may sometimes get political, the huge potential of the Olympic movement cannot be denied. Such events are a unique social phenomenon with a series of humanitarian principles based on the idea to unite the world community. The modern Olympic Games are a powerful driving force and incentive for the development of sports, promotion of the ideals of a healthy lifestyle and spiritual and moral wellbeing of youth. Sporting events reconcile important social factors and modern trends, which contribute to the development of favourable relations between peoples and the internationalization of modern sports and culture.

To conclude, this study suggests that it is always important to remember that sports is primarily intended to be a universal language of communication, uniting continents, and different peoples of the world. This means that it is necessary to realize the powerful potential of "sports diplomacy" in this vein. Fundamental principles and pillars of the Olympic movement promote a culture of peace and dialogue between civilizations.

\section{ACKNOWLEDGEMENTS}

The study is supported by the Russian Government Program of Competitive Growth of the Kazan Federal University.

\section{REFERENCES}

ANO Directorate for sports and social projects (2019). See you all in 2020: FISU Volunteer Leaders Academy 2019 wraps in Kazan, 11 Sep. 2019. Accessed from https://en.dspkazan.com/mediaroom/news/?ELEMENT_ID=15777. Accessed 21 May 2020.

Ban Ki-moon centre for Global citizens (2020). Ban Ki-moon emphasizes on the importance of achieving peace through the sports, October 7, 2018. Accessed from https://bankimooncentre.org/ban-kimoon-emphasizes-importance-achieving-peace-sports. Accessed 20 May 2020.

Beacom, A. (2000). Sport in International Relations A Case of Cross-Disciplinary Investigation. The Sports Historian, 20. https://doi.org/10.1080/17460260009443366

Beato, C., \& Silveira, A. (2018). Some Conceptual Basis for Crime Prevention in Brazil and USA: Generic Public Policies and Control Crime Programs. International Journal of Criminology and Sociology, 7, 184-195. https://doi.org/10.6000/1929-4409.2018.07.13

Beloglazov, A. (2015). Russia's policy on providing security in central Asia at the beginning of the XXI $\begin{array}{lllll}\text { century. Mediterranean Journal of Social Sciences, } 6(3 & \text { S2), } 219 .\end{array}$ https://doi.org/10.5901/mjss.2015.v6n3s2p219

Cutlip, S.M., Center, A.H., \& Broom, G.M. (1994). Effective Public Relations: 7th Edition. - N.J.: Englewood Cliffs, 6-7. 
Ilikova, L. E., \& Venidiktova, E. A. (2019). Global Migration Challenges, International Organizations and European Politics. Academic Journal of Interdisciplinary Studies, 8(4), 170-170. https://doi.org/10.36941/ajis-2019-0051

llikova, L., \& Glushkova, S. (2019). Conflictual potential of soviet borders. Edición Especial Nro, 23, 259274.

Muhametzyanov, R. R. (2014). The East and the West: From holism to dialogue through confrontation. Terra Sebus, Vol., Is, 105-116.

Murray, S. (2011). Sports-Diplomacy: a hybrid of two halves. Accessed from: http://www.culturaldiplomacy.org/academy/content/pdf/participant-papers/2011-symposium/SportsDiplomacy-a-hybrid-of-two-halves--Dr-Stuart-Murray.pdf. Accessed 17 February 2021.

Murray, S. (2013). Moving beyond the ping-pong table: sports diplomacy in the modern diplomatic environment. Public Diplomacy Magazine. -. - Winter, 14 - 15.

Neilson company (2020). How Different Genders, Ages, Races and Regions Watch the Olympics, 25 February 2010. Accessed from http://www.nielsen.com/us/en/insights/news/2010/how-differentgenders-ages-races-and-regions-watch-the-olympics.html. Accessed 19 April 2020.

Penkovtsev, R. V., \& Shibanova, N. A. (2015). Wars and Military Conflicts of the XXI Century in the Context of the Strategic Interests of the United States. Journal of Sustainable Development, 8(4), 164. https://doi.org/10.5539/jsd.v8n4p164

Tonekaboni, A. M., \& Abianeh, M. A. (2020). Information Structure of Sentences in English and Persian. Journal of Social Sciences and Humanities Research, 8(2).

UNESCO Media Services (2020). UNESCO and FIFA to enhance access for all to sport, 14 July 2020. Accessed from http://www.unesco.org/new/en/media-services/singleview/news/unesco_and_fifa_to_enhance_access_for_all_to_sportt. Accessed 20 April 2020.

Walters, C. (2007). Sports Diplomacy is the new comeback Kid. Accessed from: https://uscpublicdiplomacy.org/blog/sports-diplomacy-new-comeback-kid. Accessed 17 February 2021.

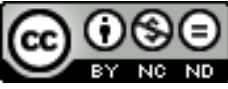

This work is licensed under a Attribution-NonCommercial-NoDerivatives 4.0 International (CC BY-NC-ND 4.0). 